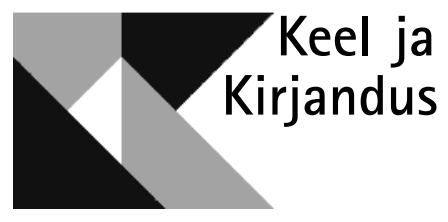

EESTI TEADUSTE AKADEEMIA JA EESTI KIRJANIKE LIIDU AJAKIRI

\title{
EESTI KIRJAKEELE TÜVEVARA PÄRITOLU ARVUDES
}

IRIS METSMÄGI, MEELI SEDRIK, SVEN-ERIK SOOSAAR

\section{Sissejuhatus}

$\mathrm{E}$ esti keele tüvede päritolu selgitamine on kestnud juba mitu sajandit. Viimase suurema kokkuvõtte tegemisest on möödunud ligi 30 aastat (Rätsep 1983). Selle aja jooksul on täpsustatud paljude tüvede etümoloogiat ning esitatud hulgaliselt uusi. Äsja ilmunud „Eesti etümoloogiasõnaraamat” (2012, edaspidi EES) võtab kokku eesti tüvede päritolu alase uurimistöö praeguse seisu. EES-ile tuginedes anname käesolevas artiklis uue, uurimistöö praegust seisu kajastava arvulise ülevaate eesti kirjakeele tüvevara päritolust.

\subsection{Tüve määratlusest}

Terminil tüvi on lingvistikas kaks tähendust. Sellega võidakse mõelda (1) mis tahes sõnaosa, millele liide liitub, või (2) lihtsalt juurmorfeemi (Karlsson 2002: 128). Näiteks „Eesti keele grammatika” annab tüve mõistele laiema tähenduse (1): tüvi on see osa sõnast, mis muutuvates sõnades seisab üksi või eelneb muutemorfeemile (EKG I: 408). Mõnikord moodustab tüve üksainus morfeem, leksikaalset tähendust väljendav juur (2) (EKG I: 409). Etümoloogias on otstarbekas määratleda tüve just kitsamalt (2), mõeldes selle all leksikaalset tähendust kandvat juurmorfeemi. Seegi määratlus ei ole aga piisav, sest 
sünkroonilise analüüsi juurest tuleb etümoloogias minna edasi diakroonilise analüüsi juurde. Tänapäeva keele seisukohalt jagamatu leksikaalne morfeem (juur) võib ajalooliselt lähtuda mitme morfeemi järjendist, st ajalooliselt sisaldada liidet või olla tekkinud mitme leksikaalse morfeemi koondumisel. Seejuures võib ajalooliselt tuletusaluseks olnud juurmorfeem olla identne mõne teise juurmorfeemiga. Nt $k a t$ - $(m a)$ on tänapäeva eesti keeles vaieldamatult jagamatu leksikaalne morfeem. Keeleajalooliselt lähtub see aga kahe morfeemi järjendist, *kante- + *tta-, kusjuures *kante- on sama juurmorfeem, mille vaste on kaas. Samuti võib juurmorfeemide esialgne identsus olla aja jooksul eri seostes toimunud häälikuliste ja semantiliste muutuste tagajärjel ähmastunud, nii et tänapäeva keele seisukohalt on tegemist eri juurmorfeemidega. $\mathrm{Nt}$ vaevalt saab keeleajalugu tundmata tulla selle peale, et nii on algselt sõna need käändevorm (instruktiiv) või et page-(ma) ja põge-(ne-ma) on ühe ja sama juurmorfeemi eri murretest pärinevad variandid. Seega kasutatakse käesolevas artiklis (nagu ka EES-is) tüve mõistet kitsamas mõttes ja keeleajaloolist aspekti arvestades: tüvi on leksikaalset tähendust kandev juurmorfeem, millest keeleajalooliselt ei saa eraldada ühtki tuletusliidet ja mida keeleajalooliselt ei saa häälikuliselt samastada ühegi teise leksikaalset tähendust kandva juurmorfeemiga. Ka Huno Rätsep (1983) on oma kokkuvõttes tüve mõistele põhimõtteliselt samamoodi lähenenud. Sõnad, millel on selle definitsiooni järgi sama tüvi, on EES-is koondatud ühte artiklisse.

\subsection{Andmete kogumise metoodikast}

EES on koostatud Eesti Keele Instituudi veebipõhises sõnastikusüsteemis EELex. Sõnaraamatu elektroonilises baasis on igale sõnaartiklile lisatud päritoluväli. Tüved, millel on ainult üks aktsepteeritav etümoloogia, on varustatud ainult ühe päritoluvõimalusega. Need on käesolevas artiklis arvestatud kindla etümoloogiaga tüvedeks. Paljude tüvede päritolu ei ole aga üheselt selge. Näiteks on (kaugemate) sugulaskeelte vasted või pakutud laenuallikas häälikulistel, semantilistel vm põhjustel kaheldavad või on tüvel mitu võrdväärset laenuallikat. Niisugused tüved on varustatud mitme päritoluvõimalusega, mis on kõik arvestatud küsitavateks (sõnaartikli kommentaariosas esitatud kaheldavad etümoloogiad kui vähem tõepärased on üldjuhul jäetud arvesse võtmata). Mitme päritoluvõimalusega tüved on küsitavatena arvesse võetud mitmes eri rühmas. Erandi moodustavad laenuetümoloogiata tüved, mille lähemate sugulaskeelte vasted on kindlad, kaugemate sugulaskeelte vasted aga küsitavad. Need on selles tüvekihis, milleni neil on kindlad vasted, arvesse võetud kindlatena, selles tüvekihis, milleni ulatuvad küsitavad vasted, aga küsitavatena. $\mathrm{Nt}$ tüvel kebja on kindlad vasted saami keelteni, lisaks sellele aga küsitavad vasted samojeedi keelteni. See tüvi on arvestatud kindlaks läänemeresoome-saami tüveks ning lisaks küsitavaks uurali tüveks. Seega on iga tüverühma juures antud vahemikuna kaks arvu. Esimene näitab vastavasse tüverühma kindlalt kuuluvate tüvede hulka, teine kindlate ja kaheldavate tüvede hulka kokku.

\section{3. „Eesti etümoloogiasõnaraamatu” tüvede üldarvust}

EES-i märksõnastiku aluseks on „Eesti õigekeelsussõnaraamatus ÕS 2006” (ÕS 2006) sisalduvad tüved. Välja on jäetud võõrtüved (kriteeriumide kohta vt EES: 25). Kokku on EES-is 6641 märksõna. Neist 1238 on viidemärk- 
sõnad, mille tüvi on (vähemalt keeleajalooliselt) sama mis mõnel põhimärksõnal. Põhimärksõnu on 5403, mis on ühtlasi suurim võimalik eri tüvede arv. Tõenäoliselt on eri tüvesid siiski vähem, sest 580 põhimärksõna on peetud võimalikuks (kuid mitte täiesti kindlaks) variandiks, tuletiseks või leksikaliseerunud vormiks mõne teise põhimärksõna tüvest. Selle arvu lahutamisel põhimärksõnade üldarvust saame vähima võimaliku eri tüvede arvu. Niisiis on EES-is 4823-5403 tüve.

\section{Omatüved}

Kõige üldisemalt võib iga keele sõnatüved päritolu järgi jagada omatüvedeks ja laentüvedeks. Omatüvedena käsitletakse tüvesid, millele ei ole leitud laenuallikat ja millel võib olla sugulaskeeltes vaste, mille saab tagasi viia samale algtüvele. Omatüved võib rühmitada tüvevarakihtideks vastavalt sellele, missugustes uurali keeltes või keelerühmades on neil vasteid.

\subsection{Uurali tüved}

Kõige vanemasse omatüvede kihti kuuluvad tüved, millel on kindlaid vasteid samojeedi keeltes: neenetsi (tundra- või metsaneenetsi), eenetsi, nganassaani, sölkupi või juba hääbunud kamassi või matori (motori) keeles. Uurali tüvesid on 97-149.

Kindlad uurali tüved on nt ala, ela-(ma), ema, ime-(ma), isa, kadu-(ma), kaks, kala, kand-(ma), keel, koer, kool-(ma), kuu, kõiv, lumi, luu, maa, meie, mina, mine-(ma), neela-( $m a)$, nool, pane-( $m a)$, pea (kehaosa), peks-(ma), pesa, pime, pure-(ma), põlv, päev, see, suusk, süda, tema, tule-(ma), uju-(ma), vask, väi, ou, üle.

Kaheldavatest uurali tüvedest on 43 sellised, mis kuuluvad kindlalt mõnda teise omatüvede kihti, sest neil on kindlaid vasteid lähemates sugulaskeeltes ja vähegi arvestatav laenuetümoloogia puudub, kuid samojeedi keelte vasted on küsitavad. Nende hulgas on 11 kindlat soome-ugri, kolm läänemeresoomepermi, kuus läänemeresoome-volga (kaks läänemeresoome-mordva-mari ja neli läänemeresoome-mordva), 11 läänemeresoome-saami ja 12 läänemeresoome tüve. Kahel tüvel (oota-( $m a)$, onu) on küll kindlad vasted lähemates sugulaskeeltes, kuid need võivad olla vanad tuletised, mitte algselt eraldi tüved. Üks tüvi $(t a)$ võib osaliselt olla teise uurali tüve $(t e-(m a))$ variant. Ühel tüvel (õeva-(ne)) on kõik sugulaskeelte vasted küsitavad. Viis tüve, millel on vasted ka samojeedi keeltes (pelga-(ma), soon, sõud-(ma), too-( $m a)$, vesi) võivad olla indoeuroopa laenud, st neile on esitatud laenuetümoloogia, mis häälikulistel või semantilistel põhjustel ei ole siiski kindel.

\subsection{Soome-ugri tüved}

Soome-ugri kihti kuuluvad tüved, millel on kindlad vasted ugri keeltes: handi, mansi või ungari keeles. Sellesse kihti kuulub 134-206 tüve.

Kindlad soome-ugri tüved on nt aht-(ma), ava-(ma), hiir 'väike näriline', ilm, jõuk, jää, kas-(t-ma), keha, kere, kivi, koda, kolm, kulm, kuus, käsi, kütke, leem, leil, luge-(ma), mõist-(ma), mägi, nai-(ne), neli, nülgi-(ma), ole-(ma), pilv, 
poeg, põu, savi, seen, seis-(ma), säga, söö-(ma), sügis, talv, täi, uus, veri, õlg 'kehaosa', öö, üks. ${ }^{1}$

Kaheldavatest soome-ugri tüvedest kuulub 58 kindlalt mõnda lähemasse omatüvede kihti (lähemate sugulaskeelte vasted on kindlad, kuid ugri keelte vasted küsitavad, laenuetümoloogia puudub). Nende seas on kaks läänemeresoome-permi, 13 läänemeresoome-volga (kaks läänemeresoome-mordva-mari, neli läänemeresoome-mari, seitse läänemeresoome-mordva), 11 läänemeresoome-saami, 31 läänemeresoome tüve ja üks lõuna-läänemeresoome (liivi ja vadja vastetega) tüvi. Kahel tüvel (aas 'rohumaa', ila) on kõik sugulaskeelte vasted küsitavad. Lisaks võivad kaks tüve (parv 'samaliigiliste lindude, kalade, putukate suurem kogum' ja kusi-(lane)) olla identsed uurali kihti kuuluvate tüvedega (vastavalt parv 'palkide kogum' ja kusi). Kaheksa võimalike soome-ugri vastetega tüve võivad olla ka laenud: aja-(ma), sool 'seedekulgla osa', tege-( $m a)$, utt (indoeuroopa), osa, reba-(ne) (indoiraani), sündi-(ma), tõug 'suvivili' (algiraani). Üks võimalike soome-ugri vastetega tüvi (taba-(ma)) võib alternatiivselt kuuluda germaani laenude hulka, sel juhul permi ja ugri vasted ei kehti. Üks tüvi (samb) võib olla identne võimaliku indoiraani laentüvega (sammas).

\subsection{Läänemeresoome-permi tüved}

Läänemeresoome-permi kihti kuuluvatel tüvedel on kindel vaste kas komi või udmurdi keeles, sageli mõlemas. Selliseid tüvesid on 42-85.

Kindlad läänemeresoome-permi tüved on nt $a m b$, ihu, jaga-(ma), jaksa(ma), jäse, kaas, kesk, kosk, kotkas, kudu-(ma), kusla-(puu), käski-(ma), lõuna, meel, neid, nema-(d), niin, okse-(nda-ma), orav, pedajas, peni, piht 'tangidekujuline tööriist', pähkel, rehi, räppen, sage, seitse, säsi, säär, tahk, tee 'rada jms', tuul, vahe-(ta-ma), äi.

Kaheldavatest läänemeresoome-permi tüvedest 33 kuulub kindlalt mõnda lähemasse omatüvede kihti (lähemate sugulaskeelte vasted on kindlad, kuid permi keelte vasted küsitavad, laenuetümoloogia puudub), neist seitse läänemeresoome-volga (kaks läänemeresoome-mordva-mari, kaks läänemeresoome-mari, kolm läänemeresoome-mordva), kuus läänemeresoome-saami ja 20 läänemeresoome kihti. Ühel tüvel (piht-(aed)) on kõik sugulaskeelte vasted küsitavad. Üks tüvi (oma) võib olla vana tuletis. Kaheksa võimalike permi vastetega tüve võivad olla ka laenud: mõni, soovi-(ma), utt (indoeuroopa), ori (indoeuroopa või indoiraani), reba-(ne), suga 'kangaspuude osa' (indoiraani), soe, sündi-( $m a)$ (algiraani), mõnel neist on ka küsitavaid soome-ugri vasteid, vt 2.2.

\subsection{Läänemeresoome-volga tüved}

Läänemeresoome-volga kihti kuuluvatel tüvedel on kindel vaste mari ja/või mordva (ersa või mokša) keeltes. Kuna mari ja mordva keelte ühise keelerühmana käsitlemine on vaieldav (nt Bereczki 1988: 314-315), on käesolevas artiklis (nagu ka EES-is) see kiht jaotatud kolme rühma, kokku on neis 103-158 tüve.

${ }^{1}$ Siin ja edaspidi on näidetes liited eraldatud eelkõige etümoloogilist aspekti arvestades. Eraldatud on selgesti mõistetavad ajaloolised liited, nt kas-t-ma, ritsi-kas. Eraldamata on jäetud omaliidetega sarnased elemendid, kui need lähtuvad laenuallikast, nt lusikas, heegelda-ma. 


\subsubsection{Läänemeresoome-mordva-mari tüved}

Sellesse rühma kuuluvad tüved, millel on kindel vaste nii mari kui ka vähemalt ühes mordva keeles. Selliseid tüvesid on vaid 18-28.

Kindlad läänemeresoome-mordva-mari tüved on hapu, ihu-(ma), jahva(ta-ma), jumal, kaheksa, kuk-(lane), kärbes, kärsi-(ma), mahtu-(ma), noo-(d), püsi-(ma), tamm (puu), tuum, täht, uhmer, vaher, vatku-(ma), üheksa. ${ }^{2}$

Kaheldavatest läänemeresoome-mordva-mari tüvedest kuut võib arvestada küll kindlateks omatüvedeks, sest lähemate sugulaskeelte vasted on kindlad ja laenuetümoloogia puudub, kuid vähemalt osa volga keelte vasteid on küsitavad. Nende hulgas on kaks läänemeresoome-mari tüve (loo-( $\mathrm{ma})$, parm), üks läänemeresoome-mordva tüvi (vast), üks läänemeresoome-saami tüvi (õige) ja kaks läänemeresoome tüve (iga 'ükskõik milline paljude hulgast', sõda). Kaks tüve, kummar-(da-ma), oota-(ma), võivad olla vanad tuletised. Kaks võimalike läänemeresoome-mordva-mari vastetega tüve võivad olla ka laenud: sidu-(ma) (indoeuroopa), järv (balti).

\subsubsection{Läänemeresoome-mari tüved}

Läänemeresoome-mari tüvedel on kindel vaste mari keeles, kuid puudub mordva keeltes. Niisuguseid tüvesid on 18-29.

Kindlad läänemeresoome-mari tüved on ammu-(li), haab, haru, kevad, künd-(ma), loo-(ma), lumma-(ma), läh-(eda-l), läila, mari, oks, parm, saar (puu), selg, sõnn-(ik), tera, valge, vars.

Kaheldavatest läänemeresoome-mari tüvedest seitse kuulub kindlalt lähematesse omatüvekihtidesse (kindlad vasted lähemates sugulaskeeltes, kuid mari vaste küsitav, laenuetümoloogia puudub), neist kaks läänemeresoomesaami (pinge, süva) ja viis läänemeresoome kihti (karga-(ma), kidu, kogu, kurvits, turd). Üks tüvi, pist-(ma), võib olla vana tuletis. Kolm võimalike läänemeresoome-mari vastetega tüve võivad olla ka laenud: leht (indoeuroopa või balti), tohti-(ma), ong (indoeuroopa).

\subsubsection{Läänemeresoome-mordva tüved}

Läänemeresoome-mordva tüvedel on kindel vaste ersa ja/või mokša keeles, kuid puudub mari keeles. Niisuguseid tüvesid on 67-101.

Kindlad läänemeresoome-mordva tüved on nt aher 'sigimatu', ase, hüva, istu-(ma), jahe, juur, kõrbe-(ma), käpp, kümme, küsi-(ma), lehm, lisa, muhk, murd-(ma), pett, pisar, poo-(ma), sattu-(ma), sopp 'sisse- või väljaulatuv osa', sõrm, sääsk, töö, vaim, õlg 'teravilja kõrs'.

Kaheldavatest läänemeresoome-mordva tüvedest 20 kuulub kindlalt lähematesse omatüvekihtidesse (kindlad vasted lähemates sugulaskeeltes, kuid mordva keelte vasted küsitavad, laenuetümoloogia puudub), enamik (16) läänemeresoome kihti: eda-(si), jama 'ühenduskoht', jära-(ma), kang 'tugev varb', kõver, laam, matsa-(kas), nali, palu-(ma), pool 'üks kahendik', sirge, sise-(mine), sõstar, tõrju-(ma), tädi, ur-(ise-ma). Kahel tüvel (kõnts, meigas) on kõik sugulaskeelte vasted küsitavad. Kaks tüve (känd, künnis) on tõenäoliselt vanad tuletised vanematesse kihtidesse kuuluvatest omatüvedest. Kaheksa võimalike läänemeresoome-mordva vastetega tüve võivad olla ka laenud:

${ }^{2}$ Tüved kaheksa ja üheksa on kujunenud sõnaühenditest, mille üks osis on olnud vastavalt uurali kihti kuuluv tüvi kaks ja soome-ugri kihti kuuluv tüvi üks. 
nidu-(ma), pese-(ma), sang, sidu-(ma), sõre (indoeuroopa), sini-(ne) (indoiraani), lepp (balti), vähe (germaani). Üks tüvi (veis) on suure tõenäosusega tuletis vanast indoeuroopa laentüvest veda-( $m a)$. Üks tüvi (tsura), millele on pakutud mordva keelte vasteid, on pigem noorem läti laen, sel juhul mordva keelte vasted ei kehti.

\subsection{Läänemeresoome-saami tüved}

Läänemeresoome-saami kihti kuuluvatel tüvedel on kindel vaste lisaks läänemeresoome keeltele vaid saami keeltes. Niisuguseid tüvesid on 110-174.

Kindlad läänemeresoome-saami tüved on nt ahven, huul, hõbe, katsu-( ma), kiru-(ma), kole, küla, luule-(ta-ma), nina, noor, nälg, org, põde-(ma), põõsas, rebi-(ma), rind, salva-(ma), sigi-(ma), sitke, uks, usku-(ma), viga, vihm, õos, ämm.

Kaheldavatest läänemeresoomi-saami tüvedest 35 on kindlate läänemeresoome vastetega omatüved, nt haar, hiilga-(ma), hool, ilu, imal, kabi, kirg, koht, kõhn, kübe, küür, laul-(ma), lible, mahl, muse-(rda-ma), paka-(ne), pude-(ne-ma), rüsi-(ma), saarmas, suits, sõõre 'ninaava', sära-(ma), taht-(ma), tuim, tõrju-(ma), vandu-(ma), õmb-(le-ma). Seitse tüve võivad olla vanad tuletised või variandid teistesse omatüvekihtidesse kuuluvatest tüvedest: jooks(ma), keela-(ma), mõnu, oja, oma, onu, tähn. 19 võimalike läänemeresoomesaami vastetega tüve võivad olla laenud: õng (indoeuroopa), osa, suga, tõo(ta-ma) (indoiraani), alli-(kas), kägu, lava, põud (balti), kare 'väike laid', kilp, paljas, püha, rahu, raiu-(ma), saun, tupp, täis (germaani), põhi (indoiraani või germaani), tõsi (germaani või balti), mõnel neist on ka küsitavaid kaugemate sugulaskeelte vasteid. Kolm tüve (kinner, laast, vait) võivad olla vanad variandid või tuletised laentüvedest.

\subsection{Läänemeresoome tüved}

Läänemeresoome kihti kuuluvatel tüvedel on kindlaid vasteid läänemeresoome keelte põhjarühma keeltes (soome, isuri, karjala, lüüdi või vepsa keeles). See on omatüvede kihtidest kõige arvukam, siia kuulub 960-1368 tüve.

Kindlad läänemeresoome tüved on nt ahm, eile, hais, halb, higi, homme, hõoru-(ma), hüppa-(ma), ilu, isu, janu, julge, jäme, jänes, kallis, kaval, kerge, kiri, kõht, kõri, külva-(ma), lenda-(ma), linn, loksu-(ma), lõke, must, naer-(ma), neem, nokk, nut-(ma), nõges, näri-(ma), põlga-(ma), päkk, püga-(ma), roie, rõivas, rööbas, saast, soo, sõrg, tatt, tibu, toru, täna-(ma), udu, urb, valmis, võlg, ôhtu, ämb-(lik), ülbe.

Kaheldavatest läänemeresoome tüvedest võib 43 pidada kitsama levikuga omatüvedeks. Neist viis on niisugused, mille põhja-läänemeresoome vasted on küsitavad, kuid liivi ja vadja või ainult liivi keeles on kindlaid vasteid (peerg, vänge, hoop, juga-(puu), loik); 38 tüvel ei ole küll üheski läänemeresoome keeles kindlaid vasteid, kuid tõenäoliselt on tegemist eesti keeles kujunenud häälikuliselt ajendatud (onomatopoeetiliste või deskriptiivsete) tüvedega, nt hasse-(ta-ma), kahk, kenka-(ma), kink 'väike küngas', koksi-(ma), mõhn, nakk, natu-(ke), näss, nöbi, pire-(ke), pupe-(rda-ma), pälk, rihk, ritsi-(kas), rämps, rühma-(ma), somp 'paks udu, hämu', sora-(kas), taiu-(ta-ma), tatsa-(ma), tuust, täkki-(ma), töga-(ma), tömp, õgi-(ma). 33 tüvel on kõik läänemeresoome vasted 
küsitavad (sageli ongi välja pakutud üksainuke vaste), kuid muu arvestatav etümoloogia puudub, nt anum, hatt 'narmas', jõhker, kama 'jama, lora', kihu 'midagi pisipeent; ivake, natuke', kurm, lasu, nõlv, närb, pugu, rõhk, rõuge-(d), toigas, viir-(puu). 196 kindlate (mõnel juhul ka küsitavate) läänemeresoome vastetega tüve võivad olla vanad tuletised või teiste tüvede (nii oma- kui ka laentüvede) variandid, nt abi-(elu), astu-(ma), eha, hall (värvus), juhtu-(ma), järg '(järje)kord; olukord, seisund', kaitse-(ma), loe, maasi-(kas), norg, oim, oska-(ma), pere, püüd-(ma), sipel-(gas), sõge, sõtse, tõmmu, tähk, võru.

135 läänemeresoome vastetega tüve võivad olla ka laenud, kusjuures mõnele tüvele on esitatud mitu võimalikku laenuallikat. Kõige rohkem on võimalikke germaani laene (63-76), nt aed, ebe, heit-(ma), hukk, hüljes, ilge, kaeba-(ma), karp 'korp, kare koorik', kehv, kurk 'kõri', lahk, lait-(ma), leba-(ma), madu, maga-(ma), mees, mäger, paas, paist-(ma), pea 'varsti', pühki-(ma), rahvas, sadam, tuhk, valu, värd, õlu, ümber. Arvukalt on ka võimalikke balti laene (35-43), nt aina, ais, aur, habe, hauku-(ma), hirs, kaur, kiivas 'armukade; äge', kinnas, kints, kõik, lein, liiv, narts, oder, pet-(ma), piim, põder, sammal, sõber, talb, teder, tolm, toores, tume, vikat, voor, õhv. Germaani või balti laenud võivad olla ale, lang, laud, mõdu, pard, peig, sima.

\subsection{Läänemeresoome lõunarühma tüved}

Läänemeresoome lõunarühma tüvedel on kindel vaste vadja ja liivi keeles või ühes neist. Siia kihti kuulub 90-130 tüve (9-11 liivi ja vadja vastega, 58-86 ainult liivi vastega, $23-33$ ainult vadja vastega).

Kindla liivi ja vadja vastega tüved on hääl, kasi-(ma), kudru-(ta-ma), niiske, peerg, puts, põrka-(ma), vänge, õel; ainult kindla liivi vastega tüved nt hakk, hoop, huuga-(ma), kiunu-(ma), kõom, loib, maru, nuust, piilu, reba, tari-(ma), tukku-(ma), vahe 'terav', vistrik; ainult kindla vadja vastega nt koku-(ta-ma), linnase-(d), lõhn, mokk, obli-(kas), piht 'vöökoht, talje; turi', uba, õun.

Kaheldavate läänemeresoome lõunarühma tüvede hulgas on niisuguseid, mille ainuke vaste on küsitav, nt pau, pint, posi-( $m a)$, rong, süga-(ma); niisuguseid, mis võivad olla mõne teise (oma- või laen)tüve tuletis või variant, nt kihv, kilk, kõrk, käi, laasi-(ma), laima-(ma), nigel, raas, sai, salk 'väiksem hulk', ning üksikuid niisuguseid, mis võivad olla ka laenud, nt lina, nakka-(ma).

\subsection{Eesti ja tundmatu päritoluga tüved}

Eesti ja tundmatu päritoluga tüved on need, millel ei ole sugulaskeeltes kindlaid vasteid ja millele ei ole esitatud ka ühtegi tõsiselt võetavat laenuetümoloogiat. Niisuguseid tüvesid on 746-816 ja need võib jagada kolme alarühma: 1) häälikuliselt ajendatud, 2) tüvede koondumisel tekkinud ja 3) tundmatu päritoluga tüved. Lisaks märgitagu siinkohal, et 580-st EES-i märksõnast, mida on peetud võimalikuks variandiks, tuletiseks või mõne teise põhimärksõna tüve leksikaliseerunud vormiks, on 266 võimalike sugulaskeelte vastete ja võimali$\mathrm{ku}$ laenuetümoloogiata.

\subsubsection{Häälikuliselt ajendatud eesti tüved}

Sellesse rühma kuuluvad need häälikuliselt ajendatud tüved, millel sugulaskeeltes kindlad vasted puuduvad. Neid on 458-520. Kindlad häälikuli- 
selt ajendatud eesti tüved on nt amps, hõika-(ma), hüüd-(ma), jabur, jonn, jõlli-(s), jüra-(ma), kappa-(ma), kissi-(s), klõmmi-(ma), koobe-(rda-ma), kriuksu-(ma), krooksu-(ma), kähku, lal-(ise-ma), lidu-(ma), limpsa-(ma), lõust, mad(is-ta-ma), mugi-(ma), mürgel, niutsu-(ma), nutt 'õisik', nööka-(ma), pah-(isema), pitsi-(ta-ma), priiska-(ma), pusi-(ma), raibe, sagi-(ma), silka-(ma), sodi, sul-(ise-ma), särtsu-(ma), tota-(kas), vonk-(le-ma), võd-(ise-ma), õrri-(ta-ma), ähm 'tuhmistav kiht, hämu', ühma-(ma).

Kaheldavad häälikuliselt ajendatud eesti tüved on enamasti niisugused, mis võivad olla ka mõne teise tüve vana tuletis või variant või identsed mõne teise tüvega (45), nt ame-(le-ma), kiilu-(ma) 'kiljuma', koge-(le-ma), kõlku-(ma), lillu-(ta-ma), lobja-(kas), lõit, muri, nilpa-(ma), näägu-(ta-ma), sihva-(kas), tibi-(ma). Samuti on nende hulgas niisuguseid, mis võivad olla ka laenud (14), nt kipa-(kas) 'ebakindel, viltu seisev', kutsu, mülgas, nüke, pulst, rekk, töss.

\subsubsection{Tüvede koondumisel tekkinud eesti tüved}

Eesti keeles sõnaühenditest või liitsõnadest mitme tüve koondumisel, samuti eri tüvede segunemisel tekkinud tüvesid on 36-44.

Kindlad tüvede koondumisel tekkinud uued tüved on nt aasta, aituma aitäh, külimit, künnap, millal, nagu, ning, nõnda, paharet, pilgar, praegu, teistre, tänavu, uibu, veski, ööbik.

\subsubsection{Tundmatu päritoluga tüved}

252 tüve päritolu on tundmatu. Nende hulgas on esiteks tüved, mille päritolu kohta ei ole ühtki arvamust (65), nt helpi-(ma), kaan, kirre, krohv, kunel, kärk, luide, noomi-(ma), nurg, nägur, piid-(le-ma), pistr-(ik), ruuge, suir, tirel, vadak, vôllas, üla-(ne). Teiseks on siia rühma arvatud tüved, mille kohta on küll välja pakutud, et need võivad olla häälikuliselt ajendatud, kuid pigem pärinevad nad siiski muust, seni tundmatust allikast (74), nt aps, jäle, kaba, klunn, leitse, luni-(ma), lüll, mutt (loom), nuga, onn, plonn, praht 'risu, kolu', põis, rong, riitsi-( $m a)$, sirvi-(ma), tiir 'ring', äsa-( $m a)$ (mõnel neist võib olla küsitavaid vasteid sugulaskeeltes). Kolmandaks leidub siin tüvesid, mille päritolu kohta on esitatud üksnes oletusi, sealhulgas pakutud lähtekohti, mida ei ole kirjalikes allikates registreeritud (111), nt alp, ask, igri-(tse-ma), jube, kalk-(vel), kena, kesv, kiiba-(kas), kili, kõder, lüdi, muru 'tihe rohi', naaskel, nori-(ma), pooki(ma) 'köitma', puskar, pundar, põll, pärg, pürg, rass, rõhu-(ma), tardu-(ma), trimpa-(ma), uit, vassi-(ma), vemp, vidu, äsja.

\section{Laentüved}

Laentüved on teisest keelest laenatud. Mõnel juhul on laenuallikaks olnud tuletis, st laen sisaldab laenuandjakeele liidet. Samuti leidub tervikuna laenatud liitsõnu. Niisugustel juhtudel oleks mõnikord õigem rääkida laentüvede asemel laensõnadest. Kuna käesoleva artikli seisukohast on eelkõige tähtis laenude hulk, ei ole siin laentüvesid ega laensõnu terminoloogiliselt eristama hakatud. Laenatud ühe ja sama tüve tuletised ning liitsõnad on arvestatud eraldi laenudeks.

Laentüvesid rühmitatakse laenuperioodi ja laenuandjakeelte järgi. Laenuaja järgi võib laentüved kõige üldisemalt rühmitada vanemateks ja uuemateks. 


\subsection{Vanemad laenud}

Vanemad laenud pärinevad ajast enne praegu tuntud uurali ja indoeuroopa keelte omaette keelteks kujunemist. Need on laenatud mõnda uurali keelte varasemasse varianti, mis on olnud eesti keele ja (kõigi või osa) tänapäeva uurali keelte ühine eelkäija, ning laenuallikaks on olnud mõni indoeuroopa keelte varasem variant, mis on olnud mitme tänapäeva indoeuroopa keele ühine eelkäija. Seega on vanematel laenudel alati vasteid vähemalt osas sugulaskeeltest. Vanemad laentüved on kaasa teinud arengu mõnest varasemast keelevariandist tänapäeva keelteni, alludes samadele muutustele nagu omatüvedki. Vanemate laenude hulka kuuluvad indoeuroopa, indoiraani ja algiraani, balti, germaani, skandinaavia ja vanavene laenud.

\subsubsection{Indoeuroopa laenud}

Indoeuroopa laenud on pärit ajast, mil tõenäoliselt ei olnud veel üksteisest eraldunud ei indoeuroopa keelkonna harud ega ka uurali keelkonna harud. Kontaktide hiliseimaks võimalikuks algusajaks on oletatud IV aastatuhande algust eKr (Koivulehto 1999: 231). Indoeuroopa laenude hulgas on tüvesid, mil on vasteid kõigis uurali keeltes, sh samojeedi keeltes, kuid ka tüvesid, mille levik piirdub ainult läänepoolsemate keeltega või isegi ainult läänemeresoome keeltega (nt puhas, maja). Seda võib seletada vastavate tüvede aja jooksul kaugematest sugulaskeeltest kadumisega või sellega, et uurali-indoeuroopa kontaktala on paiknenud suhteliselt läänes ning kõik laenud ei levinudki tollase uurali keeleala idapoolsemasse ossa (Koivulehto 1999: 231). Kitsamalt levinud laenude vanusele osutavad häälikulised seigad (Koivulehto 1999: 209). Indoeuroopa laentüvesid on 16-40.

Kindlad indoeuroopa laentüved on nt iva, mesi, mõsk-(ma), mü̈̈-(ma), nimi, os-(t-ma), puhas, puhti-(ma), punu-(ma) 'kokku keerutama; palmima, põimima', pura, sool 'kristalne aine', sõlg, veda-(ma), vii-(ma), vili.

Kaheldavatest indoeuroopa laenudest kolme puhul on võimalikuks peetud ka natuke hilisemat laenamist, tegu võib olla indoiraani (ori), germaani (rõht) ja balti laenuga (leht). Ülejäänud 20 tüve puhul on indoeuroopa päritolu häälikulistel, semantilistel vm põhjustel kaheldav ja need võivad olla omatüved, nt aja-(ma), maja, mõni, nidu-(ma), pelga-(ma), pese-( $m a)$, sang 'kaarjas käepide', sidu-(ma), sool 'seedekulgla osa', soon, soovi-( $m a)$, susi, sõre, sõud-(ma), tege$(m a)$, tohti- $(m a)$, too- $(m a)$, utt, vesi, õng. Üks tüvi võib olla vana tuletis teisest tüvest $(r o h t)$.

\subsubsection{Indoiraani ja algiraani laenud}

Indoiraani laenud pärinevad ajajärgust, mil nii indoeuroopa keelkond kui ka uurali keelkond olid juba harunema hakanud. Vanimad neist võivad olla saadud III aastatuhande alguses eKr (Koivulehto 1999: 215). Laenud on saadud keelekujust, mis on olnud tänapäeva India (nt hindi, bengali, singali), Iraani (nt pärsia, osseedi, puštu) ja Nuristani keelte ühine eelkäija. Üksikuid tüvesid on peetud hilisemateks, algiraani laenudeks, st need on laenatud pärast indoiraani keelte edasist lahknemist, keelekujust, mis on olnud Iraani keelte ühine eelkäija. Indoiraani laentüvedel võib olla vasteid kõigis soome-ugri keelte rühmades, kuid siingi on neid, mis esinevad vaid läänepoolsemates keelerühmades. Seda on seletatud kontaktala paiknemisega suhteliselt läänes (Koivulehto 
1999: 232-233). Samojeedi keeltes vasted puuduvad. Indoiraani laentüvesid on 20-33 ja algiraani tüvesid 2-6.

Kindlad indoiraani laentüved on $a b i$, aru 'mõistus, taip', iha, keder, marrask, ora, paks, paras, petkel, põrsas, saa-(ma), sada, sarv, tarn, udar, vang 'sang, käepide; jõekäär', varss, vasar, vasi-(kas), viha. Algiraani laentüved on era ja $m a k s-(m a)$.

Kaheldavatest indoiraani laentüvedest on neljal tüvel alternatiivne laenu- etümoloogia: indoeuroopa (ori), germaani (peie- $(d)$, põhi, mõlemad võivad olla ka omatüved), germaani või balti (tala). Ülejäänutel (osa, reba-(ne), sammas 'post, tulp', sini-(ne), suga, ternes, tõo-(ta-ma)) alternatiivset laenuetümoloogiat ei ole, indoiraani päritolu on kaheldav häälikulistel, semantilistel vm põhjustel. Seega võivad need tüved olla ka omatüved. Üks tüvi, vihka-(ma), võib olla läänemeresoome tuletis indoiraani laentüvest viha, üht tüve (terve) on peetud ka vanaks tuletiseks balti laentüvest tõrv. Kaheldavad algiraani laentüved, nagu ahne, soe, sündi-(ma), tõug 'suvivili', võivad kuuluda ka omatüvede kihtidesse vastavalt sugulaskeelte vastetele.

\subsubsection{Balti laenud}

Balti laenud on saadud alates II aastatuhandest või isegi III aastatuhande lõpust eKr kuni umbes $\mathrm{V}$ sajandini eKr, keelekujust, mis on olnud balti keelte (leedu, läti, preisi) ühiseks eelkäijaks. Balti laenudel on enamasti vasteid ainult läänemeresoome keeltes, laenamise ajal oli läänemeresoome keelerühm teistest uurali keeltest juba eraldunud, kuid ei olnud veel välja kujunenud tänapäevaseid läänemeresoome keeli. Umbes 30 balti laentüvel on vaste lisaks läänemeresoome keeltele ka saami keeltes, mõnel ka mordva keeltes, üksikutel isegi mari keeles. Võimalik, et saami ja mordva keeltesse on balti laenud kulgenud läänemeresoome keelte vahendusel, kuid välistada ei saa ka otsekontakte (Vaba 2011). Balti laentüvesid on 162-235.

Kindlad balti laentüved on nt aas 'silmus', aeg, ahas, ahing, angerjas, ehmes, hagu, haljas, hammas, hari, hein, hernes, hirv, hõim, härg, ihne, jäär, kael, kahv, kaim, karv, kaust, keris, kiit-(ma), kirs, kirst, kirves, kold, kõblas, kõrs, kärg, labidas, lahja, laisk, liig, luht, luud, lõhi, lõug, länn-(ik), malk, mets, mõrsja, nõbu, oinas, puder, ratas, regi, seeme, sild, tara, tiine, vagu, vaha.

Kaheldavatest balti laenudest 21 tüvel on alternatiivne laenuetümoloogia. Nende hulgas on võimalikud varasemad, indoeuroopa (leht, võib olla ka omatüvi) ja indoiraani laenud (tala, võib olla ka germaani laen). Kõige suurema rühma moodustavad tüved, millel on teise päritoluseletusena esitatud germaani etümoloogia, neid on 14 (nt kari 'loomade rühm', roog 'kõrs', rukis, vai, viru-(lane)). Neist kaheksal tüvel on laenuetümoloogia kaheldav ja need võivad olla ka omatüved. Kaks tüve võivad olla ka skandinaavia laenud: rand, rangi- $(d)$. Sugulaskeelte vasteteta kaheldavad balti laenud on kartsas ja õis(vesi). 44 kaheldaval balti laentüvel on balti päritolu kaheldav häälikulistel, semantilistel vm põhjustel ja need võivad olla omatüved. Nende hulgas on kõige rohkem võimalikke läänemeresoome tüvesid (vt 2.6). Seitsmel juhul võib tegemist olla vana tuletise või tüvevariandiga, mitte iseseisva tüvega: ait, kannel, kõnge-(ma), laid 'väike saar', ranne, taim, tõug (nt loomadel). 


\subsubsection{Germaani laenud}

Germaani laenud on saadud keelekujust, mis on olnud germaani keelte ühiseks eelkäijaks. Need laenud on läänemeresoome keeltesse jõudnud alates II aastatuhande teisest poolest eKr kuni I aastatuhande esimeste sajanditeni pKr (millest alates võib rääkida juba skandinaavia laenudest) (Hofstra 1985: 387; LÄGLOS I: XXIII). Germaani laentüvesid on 193-315.

Kindlad germaani laentüved on nt ader, aer, agan, armas, eit, hame, haud, hõlm, ind 'emaslooma sugukihu', juus, juust, kade, kalju, kallas, kana, kangas, katel, kaunis, kaup, kell, kihl, king, kuningas, käi-(ma), laev, lama-(ma), lammas, leib, luna, muda, muld, mõrd, mõók, nael, nahk, narmas, nõel, paik, parras, pind 'pealmine kiht', puri, purre, põld, rada, raha, rasv, rooste, sadul, sama, suur, tarvis, tina (metall), tuba, umbes, vaev, varas.

Kaheldavate germaani laentüvede hulgas on kaks suuremat rühma, mille puhul on germaani laenuetümoloogia kõrval balti või skandinaavia etümoloogia. Balti või germaani laentüvede näiteid vt eestpoolt (3.1.3). Germaani või skandinaavia laentüvesid on 17 , nt ankur 'kinnitusvahend', kibu 'kapp, puunõu', laen, lage, lai, naast, nobe, pila-(sta-ma), tôbi. Alati ei ole võimalik kindlaks teha, millal on tüvi laenatud, ja nii tuleb arvestada germaani ja/või skandinaavia laenu võimaluse kõrval ka vanarootsi ja/või rootsi laenuga, nt $a t t$, kelk, ladu, madar, napp 'väike (puu)nõu'. 89 juhul on laenuetümoloogia kaheldav häälikulistel, semantilistel vm põhjustel. Seega võivad need tüved olla omatüved, vastavalt sugulaskeelte vastetele eesti-liivi, läänemeresoome, läänemeresoome-saami, läänemeresoome-mordva tüved. Kõige suurem on võimalike läänemeresoome tüvede rühm (vt 2.6). Kaks tüve, natt 'vähipüügiriist' ja tang, on sugulaskeelte vasteteta kaheldavad germaani laenud.

\subsubsection{Skandinaavia laenud}

Skandinaavia laenud on germaani laenudest natuke hilisem laenurühm. Need on saadud keelekujust, mis on olnud skandinaavia keelte ühiseks eelkäijaks, alates II-III sajandist kuni skandinaavia keelte harunemiseni IX sajandil pKr (Hofstra 1985: 387; LÄGLOS I: VIII). Skandinaavia laentüvesid on 29-62.

Kindlad skandinaavia laentüved on nt haju-(ma), jõulu-(d), kari 'veealune kõrgendik', koon, kult, küünal, noot 'teatud võrkpüünis', piit, põrk, raun, riid, rooki-(ma), saad, särk 'rõivaese', taak, taud, tursk, tõld, tänav, türn-(puu), vari.

Alati ei ole germaani ja skandinaavia laenude eristamiseks piisavalt häälikulisi kriteeriume. Seepärast on kõige rohkem tüvesid, mille puhul skandinaavia laenuetümoloogia kõrval on võimalik germaani laenuetümoloogia (vt 3.1.4). Lisaks on kaheldavate laenude hulgas veel võimalikke vanarootsi ja rootsi laentüvesid. 14 juhul ei ole laenamine kindel, nt ent, haldjas, rait, rü̈ü$p a-(m a)$, siig, tila, täbar, seega võivad needki olla omatüved.

\subsubsection{Vanavene laenud}

Vanavene laenurühm hõlmab vene keele varasematest arenguastmetest pärinevaid, peamiselt vanavene laene. Idaslaavi hõimud jõudsid läänemeresoomlaste naabrusse praeguse Loode-Venemaa alal eri hinnangutel V-VIII sajandil, niisiis on need laenud saadud alates I aastatuhande teisest poolest kuni vanavene perioodi lõpuni XIV sajandil (Mägiste 1962: 67; Must 2000: 11; Blok- 
land 2009: 17). Oletused veelgi varasemate slaavi kontaktide ja laenude kohta on ebakindlad. Vanavene laentüvesid on 41-54.

Kindlad vanavene laentüved on nt aken, hurt, kalits, koonal, koost, liud, lodi, lusikas, määr 'hulk, kogus', nädal, raamat, rist, saabas, sirp, tapper, tuhkur 'tõhk', turg, vaba, vaen, varb-(lane), võlu, värav, värten.

Kaheldavate vanavene laentüvede hulgas on 11 alternatiivse laenuetümoloogiaga tüve. Kõige rohkem - kaheksa - on tüvesid, millel on vanavene etümoloogia kõrval vene etümoloogia: kalts, niit 'mittevillane lõng', paja-(ta-ma), piits, raada-(ma), raatsi-(ma), raja 'piir', sõir. Nende puhul ei ole suudetud laenuaega täpselt kindlaks teha. Lisaks on kaks võimalikku germaani laenu (astel, perv) ja üks võimalik balti laen (lina). Üks tüvi, västar, on ainult kaheldava vanavene etümoloogiaga ja sugulaskeelte vasteteta.

\subsection{Uuemad laenud}

Uuemad laenud pärinevad ajast, mil eesti keelt on juba võimalik pidada omaette keeleks. Need on laenatud keeltest, millega eesti keelel on olnud selle aja jooksul kontakte. Uuemad laenud on eesti keelde laenatud sugulaskeeltest sõltumatult (võimalikud on rööplaenud sugulaskeeltesse). Uuemate laenude hulka kuuluvad vanarootsi, rootsi, eestirootsi ja soomerootsi, alamsaksa, saksa, baltisaksa, vene, läti, soome laenud ning üksikud muudest keeltest saadud laenud.

\subsubsection{Vanarootsi laenud}

Vanarootsi laenud on saadud rootsi keele vanemast arenguastmest, vanarootsi keelest, mille kestuseks võib lugeda ajavahemikku IX sajandist XVI sajandi esimese veerandini (Raag 1988: 658). Vanarootsi laentüvesid on 14-33.

Kindlad vanarootsi laentüved on agul, kaal 'kaalikas', kaap, kadalipp, kirn, käru, küüt 'edasiviimine, vedamine', lauter, parkal, piin, pipar, plett 'juuksepalmik', rootsi, siuna-(ma).

Kaheldavate vanarootsi laentüvede hulgas on eeskätt tüved, mille puhul ei ole võimalik kindlaks teha, millisest keelekujust need on laenatud. Tegemist võib olla juba eespool nimetatud varasemate, germaani või skandinaavia laenudega (vt 3.1.4 ja 3.1.5). Samuti ei saa alati kindlaks teha, kas tüvi on laenatud vanarootsi või rootsi keelest, nt härra, tünder, või hoopiski vanarootsi või alamsaksa keelest, nt laadik, moon 'toidukraam', nunn, reede.

\subsubsection{Rootsi laenud}

Rootsi laenud on tulnud eesti keelde põhiliselt (uus)rootsi keelest XVI-XVII sajandil, kui Eesti- ja Liivimaa kuulusid tervenisti või osaliselt Rootsi võimu alla (Raag 1988: 661-662). Rootsi laentüvesid on 61-140.

Kindlad rootsi laentüved on nt halva-(ma), iil, kann 'valamistoruga nõu', korp 'kohupiimakattega sai', kortsi-(ma), kriim, kroonu, lant, malm, moor, mündrik, näkk 'veehaldjas', pagar, peiar, piip, piisa-(ma), plagu, plasku, plika, riim-(sool), riiva-(tu), rumm, ruut 'nelinurk', rätsep, sekk, soop 'seebi(keedu)pära', säng, tiidus, tuder, vaar 'vanaisa', vist, ärtu, äss.

Kaheldavatest rootsi laenudest moodustavad enamiku need, millel on alternatiivne laenuetümoloogia. Nende hulgas on juba eespool nimetatud võimalikud varasemad, germaani, skandinaavia ja vanarootsi laenud (vt 3.1.4, 3.1.5 
ja 3.2.1). Kõige rohkem (42) on tüvesid, mis võivad alternatiivselt olla laenatud alamsaksa keelest, nt just, lahing, lüht, munk, märss, niplis, nupp, pakk 'laevateki kõrgem osa', pung 'rahakott', puuk 'kratt', pärssi-(ma), pöök, rakk 'raud raa hoidmiseks masti küljes', ruhv, rünk, taldrik, telling, tikk 'väiksem puupulk', tipp 'väljaulatuv ülaosa, hari', tiss, tokk 'väike lõngaviht', triivi-(ma) 'tihtima', trükkal, tull, tääv, vürst, ü̈̈r. Nende tüvede laenuallikate eristamiseks ei ole keelelisi kriteeriume. On ka võimalik, et laenati mitu korda, kord ühest, siis teisest allikast, või ühtedesse murrakutesse ühest keelest, teistesse teisest. Kaheksa tüve puhul on lisaks rootsi ja alamsaksa keelele võimalik ka laenamine saksa keelest: ankur 'vaadikujuline nõu', kahvel 'kahvelpurje ülaäärt hoidev puu', pootshaak, pootsman, tali 'rippuv tõsteseade', toppa-( $m a)$, tragi 'otsiankur', tross. Üldjuhul on need paljudes keeltes tuntud merendussõnad, mille täpse laenuallika kindlakstegemiseks puuduvad samuti keelelised kriteeriumid. 23 tüve puhul on rootsi laenu alternatiiviks saksa laen, nt hiiva-(ma), jobi, kindral, mall 'nurgamõõdik', mamma, puht, tanta, tubakas, tükk 'kahur', vant. Kuus tüve võivad teise võimalusena olla laenatud soome keele kaudu, sel juhul on tüvi soome keeles rootsi laen: jaala, korp 'ronk', murjan, norss, rulla-(ma), topsel.

Viie tüve puhul on rootsi etümoloogia kaheldav häälikulistel, semantilistel vm põhjustel, kuid praegustel andmetel on see ainus seletus tüve päritolu kohta: kentsa-(kas), klutt, marakratt, pliiats, riisk.

\subsubsection{Eestirootsi ja soomerootsi laenud}

Eestirootsi laenud on saadud Lääne-Eesti saartel ja Loode-Eestis elanud eestirootslastelt. Püsiv rootslaste asustus tekkis Lääne-Eesti saartel ja Loode-Eesti rannikul ajavahemikus XIII-XV sajandini; Eestisse tuldi tõenäoliselt otse Rootsist, hiljem saabus uusi asukaid lisaks peamiselt Soome rootsikeelsetelt aladelt (Tiberg 1962: 19-25; Raag 1988: 725). Eestirootsi laentüvesid on 21-29.

Kindlad eestirootsi laentüved on nt haala-(ma), hauskar, julla, kepp, klibu, klomp, kratt, nugi-(ma), räim, tont, viiger.

Kaheldavate eestirootsi laenude puhul on võimalik, et laenatud on rootsi keelest (tups), rootsi keelest või soomerootsi murretest (holm), soomerootsi murretest (rool), alamsaksa keelest (viik), baltisaksa murdest (karbus), alamsaksa keelest või baltisaksa murdest (porss), soome keelest või soomerootsi murretest (päss 'jäär'). Ühe tüve puhul (krunn) on ainsana välja pakutud kaheldav eestirootsi laenuetümoloogia.

Soomerootsi laentüvesid on kuni kuus. Need on saadud Lõuna-Soome rootslastelt, rohkem on neid murretes. Sõnas simman on nähtud soomerootsi laenu. Soomerootsi laentüved võivad olla veel holm, padina-(d), päss 'jäär', rool, seila- $(\mathrm{ma})$.

\subsubsection{Alamsaksa laenud}

Alamsaksa laenud on pärit eeskätt keskalamsaksa keelest, mida kõnelesid XIII sajandi algul Eesti ala vallutanud ristisõdijad ja nende järel siia tulnud vaimulikud, ametnikud, kaupmehed ja käsitöölised. Alamsaksa keel oli Eesti alal ametlik keel kuni XVI sajandi teise pooleni, mil linnadesse hakkas tulema ülemsaksa keele kõnelejaid ja tasapisi tõrjuti alamsaksa keel kõrvale (Rätsep 1983: 546). Kõnekeelena säilis alamsaksa keel XVIII sajandi teise pooleni ja 
kohati isegi XIX sajandi teise pooleni (Ariste 1937: 135). Alamsaksa laentüvesid on 476-659, see laenurühm on eesti keeles kõige suurem.

Kindlad alamsaksa laentüved on nt aam, amet, arst, haamer, heegel-(dama), hing 'ukse, akna vms kinnitusosa', hunt, häärber, höövel, ingel, jaht, jakk, jünger, kabel, kamber, kapp 'mööbliese', karske, kast, kelm, kiht, kilter, kink 'vastutasuta antud ese, vara vms', klaas, kokk, kook, kool 'õppeasutus', korsten, korv, kriit, kruus 'jooginõu', köök, kütt, laat, lehter, liim, meister, mold, müür, naaber, neer, orel, paar 'kaks kokkukuuluvat eset või olendit', pann, prii, pärm, püss, ruum, saag, sült, tool, undruk, vorst, väärt, óli.

Kaheldavatel alamsaksa laentüvedel on enamasti alternatiivne laenuetümoloogia. Nagu juba eespool rootsi laenude juures on nimetatud, ei ole alati keelelisi kriteeriume alamsaksa ja rootsi laenude eristamiseks, samuti ka alamsaksa ja saksa laenude eristamiseks. Nii moodustavadki kaheldavate alamsaksa laenude hulgas kaks suuremat rühma tüved, mille puhul on võimalik ka saksa (116) või rootsi (42) keelest laenamine. Alamsaksa või saksa laenud on nt ahv, almus, haak, härm 'meelepaha', hütt, kang 'kitsas käik', kiiker, kiil (veesõidukil), klaar, klatt, kraan, last, lekki-(ma), loor, luuk, mant, mast 'post', müts, niker-(da-ma), nüppel, paak 'kaldamärk, tuletorn', pall, passi-(ma), pekk, pilt, pintsel, plank 'kitsam laud; tara', praali-(ma), prill, punn 'prunt', punt, raa, ramm 'sissetagumis-, kinnitampimisvahend', rant, rihv 'kivirähk, klibu', rükki-(ma), saal, taaler, teemant, tekk (laeva osa), telli-(ma), tokk 'kepp', tonn, toon, toos, traat, trahv, tripp, vaart, vamm, vanku-(ma), vinn 'vistrik', vokk. Alamsaksa või rootsi laene vt 3.2.2.

Alternatiivse laenuetümoloogiana võib kaheldavatel tüvedel olla veel vanarootsi (vt 3.2.1), baltisaksa (kalkun, timp, trits, nüke, porss), üksikutel juhtudel veel muu algupära.

Üheksa kaheldavat alamsaksa laentüve (neist neljal on ka saksa laenu võimalus) võivad alternatiivselt olla häälikuliselt ajendatud omatüved, kas läänemeresoome (st neil on võimalikke vasteid teistes läänemeresoome keeltes, nt tömp) või eesti tüved (st võimalikke vasteid sugulaskeeltes ei ole, nad võivad olla eesti keeles iseseisvalt kujunenud, nt krimps, tipp 'täpp'). Seitse kaheldavat laenu võivad olla hoopis mõne teise tüve tuletised või variandid. 13 tüve puhul on alamsaksa etümoloogia kaheldav häälikulistel, semantilistel vm põhjustel, kuid muid päritoluseletusi ei ole: karp 'kastike', kemp-(le-ma), kiivas 'viltune', kuub, lamu, ork, peldik, redu, tempi-(ma), trulling, tutt, tuur (kala), väär 'rõdu, eriti kirikus'.

\subsubsection{Saksa laenud}

Saksa laenud on saadud ülemsaksa keelest, mis hakkas XVI sajandi teisest poolest siginema Eesti linnades alamsaksa keele kõrvale ja tõrjus selle lõpuks hoopis välja (Rätsep 1983: 547). Ülemsaksa keel tuli kasutusele kõigepealt kirjandusliku ja kantseleikeelena, kõnekeelena hakkasid seda alguses tarvitama haritumad kihid. Ülemsaksa keele levikule aitasid kaasa uued ülemsaksakeelsed ametnikud, kes tulid siia pärast XVII sajandi alguse katku (Ariste 1940: 36-37). Saksa laentüvesid on 356-506.

Kindlad saksa laentüved on nt aabits, hakki-(ma), hangel-(da-ma), haspel, hekk, hirss, jope, jä̈̈ger, kaller, kalmus, kamm, kantsel, kardin, kartul, kett 'liikuvalt ühendatud lülide kogum', kips, kirss, klamber, klants, klapp, kleepi(ma), kleit, klots, kohver, kork, kraam, krell, kress, kunde, kurk, kutsar, kärner, 
laadung, leen, leier, mamsel, mürt, naps, number, parun, pirn, plats, pross 'rinnaehe', rehken-(da-ma), sahtel, sink, sirm, tass, velsker, vooster, vürts.

Kaheldavatel saksa laentüvedel on enamasti muu võimalik laenuetümoloogia. Kaks suuremat rühma moodustavad tüved, mis võivad alternatiivselt olla laenatud kas alamsaksa või rootsi keelest. Näiteid nende kohta on toodud eespool (vt 3.2.2 ja 3.2.4). 12 tüve võivad olla laenatud ka vene keelest, nt $k u$ raas, nuut, palitu, pitsat, poolakas, prohvus, sall, sits. Viis tüve võivad olla hoopis identsed teiste tüvedega: nips, plätser-(da-ma), tarre-(ta-ma), iivel-(da-ma), klaps. Kaks tüve võivad alternatiivselt olla häälikuliselt ajendatud eesti tüved: nutsi-(ma), niku-(ta-ma). Kolme tüve puhul on kaheldav saksa etümoloogia ainuke päritoluseletus: leesk-(putk), maat-(uss), mumm 'surnu (vaim), koll'.

\subsubsection{Baltisaksa laenud}

Baltisaksa laenud on pärit Baltimaadel XVII-XVIII sajandil väljakujunenud ja XIX sajandil ning XX sajandi alguskümnendeil üldiselt kasutusel olnud alamsaksa sugemetega ülemsaksa murdest (Kiparsky 1936: 10-12; Rätsep 1983: 547). Baltisaksa laentüvesid on 43-56.

Baltisaksa laentüved on nt aasi-(ma), aplaager,juker-(da-ma), kaadervärk, kemmerg, krõll, kuul, käärkamber, latter, leng, nagi, opman, paburits, pürjel, redel, redis, sahver, sirel, soni, tengelpung, traagel-(da-ma), traks 'vahend riietuseseme ülalhoidmiseks', trikkel, tärklis, villi-(ma), värvel.

Enamikul kaheldavatel baltisaksa laentüvedel on alternatiivne laenuetümoloogia, kas alamsaksa (vt 3.2.4), saksa (pits 'napsiklaas', pressi-(ma)), rootsi (klimp, purk), eestirootsi (porss) või vene (troska). Üks baltisaksa etümoloogia (riiv 'sulgemisvahend') on kaheldav häälikulistel põhjustel, kuid muud päritoluseletust ei ole.

\subsubsection{Vene laenud}

Vene laene on eesti keelde tulnud XV sajandist alates (Must 2000: 11). Vene laentüvesid on 228-274.

Kindlad vene laentüved on nt abar, arssin, jaam, kaatsa-(d), kamanda(ma), kamp 'salk, rühm', kapsas, karman, kasakas, kirka, kiisu, kirmas, kobras, koni, konku, kopsik, kõrts, lootsik, majakas, munder, nari, paaru-(ta-ma), parisnik, pintsak, pirukas, pogri, prussakas, präänik, puravik, putka, ranits, riisikas, rups, sara, sedelgas, sinel, suli, suti-(ke), tassi-(ma), tatar, tolvan, trahter, truup, tubli, tõlk, vaari-(ta-ma), verst, voli, vurle.

Kaheldavate vene laentüvede hulgas on kaheksa võimalikku varasemat, vanavene laenu (vt 3.1.5), 12 võimalikku saksa (vt 3.2.5) ja üksikuid teisi laene. Kaks tüve võivad alternatiivselt olla häälikuliselt ajendatud omatüved (torka-( $m a)$ läänemeresoome, nehku-(gi) eesti tüvi või tuletis) ja kaks tüve tuletised muudest tüvedest (roit-( $m a)$, räbik). 14 tüve puhul on vene etümoloogia kaheldav häälikulistel vm põhjustel, kuid on seni ainuke päritoluseletus, nt junts, liisk, mehka, räsi-(ma), sohk, sudima 'rassima; peksma', surnuk, timukas, trett, tuhknai, vatsk, vuhva.

\subsubsection{Läti laenud}

Läti laenud on eesti keelde tulnud alates VIII sajandist, kontaktid hakkasid elavnema tõenäoliselt XIII sajandist (Rätsep 1983: 546; Vaba 1997: 504). Läti laentüvesid on $31-43$. 
Kindlad läti laenud on nt kanep, kauss, kiin (terariist), kuut, kõuts, labus, lääts, magun, mait, mulk 'Mulgimaa elanik', nuum, pakal, palakas, pastel, rauts, rääts 'korv', sard, sõkal, vanik, viisk.

Kaheldavate läti laentüvede hulgas on üks võimalik baltisaksa laentüvi (kukkel) ja üks võimalik vene laentüvi (ting). Üks tüvi võib teisalt olla läänemeresoome-mordva omatüvi (tsura). Üheksa tüve puhul (karask, kaugas, kippel, konu, nägal, pälvi-(ma), rask, sutt, tumm 'limane leem') on läti etümoloogia kaheldav häälikulistel vm põhjustel, kuid see on ainus päritoluseletus.

\subsubsection{Soome laenud}

Suurem osa soome laenudest on kirjakeeles teadlikult kasutusele võetud. Varasemad neist laenati XIX sajandi lõpus, suurem osa keeleuuenduse käigus XX sajandi esimesel veerandil; üksikuid sõnu on soome kirjakeelest laenatud ka hiljem (Rätsep 1976: 211-212). EES-is on eraldi soome laenudeks arvatud ka tuletised eesti keeles esinevatest tüvedest, mis vormi või tähenduse tõttu on kahtlemata soome keelest laenatud. Soome laene on 197-212.

Kindlad soome laenud on nt aade, aare, aine, aldis, anasta-(ma), ehe, haihtu-(ma), halda-(ma), harras, hetk, huvi, julm, kehuta-(ma), keskust(e)le-(ma), kiindu-(ma), kirbe, kirgas, korva-(ma), kummaline, kuulu-(ma), lakka-(ma), lelu, levi-(ma), lohuta-(ma), matk, masenda-(ma), melu, mugav, neste, oivaline, orb, pädev, raev, reibas, retk, rivi, ründa-(ma), saabu-(ma), sangar, seikle( $m a)$, solva-(ma), soosi-(ma), suju-(ma), sääst-(ma), sünge, taotle-(ma), tehas, toot-(ma), uje, vaist, valluta-(ma), veet-(ma), vihja-(ma), ööbi-(ma), üllata-(ma).

Kaheldavatest soome laentüvedest kuus võivad olla laenatud ka rootsi keelest (vt 3.2.2), üks soomerootsi (seila-(ma)) ja üks soomerootsi või eestiroot-

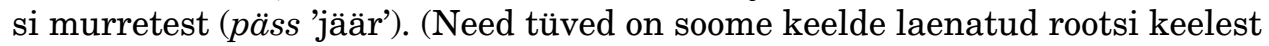
või murretest.) On ka üks võimalik alamsaksa (murjan) ja saksa või vene laen (topsel). Viie sõna puhul ei ole soome keelest laenamine kindel, neis võib olla ka kas eesti keeles ainult selles sõnas säilinud läänemeresoome tüvi (ahker, tohu-(tu)) või on need eesti keeles moodustatud teisteski sõnades esinevatest tüvedest (kangasta-(ma), lapi, maismaa).

\subsubsection{Muud laenud}

Muudest keeltest laenatud tüvesid on üksikuid, 6-18.

Kindlad laenud muudest keeltest on jaana-(lind) (heebrea keelest), jospel (jidiši keelest), mangu-(ma) (mustlaskeelest), morn (prantsuse keelest), nulg (mari keelest) ja vutt 'jalgpall' (inglise keelest).

Kaheldavad muude keelte laenud on eelkõige niisugused tüved, mis teisalt võivad kuuluda ka mõnda eespool nimetatud laenurühma. Nende hulgas on merendussõnu, mille ühe võimaliku laenuallikana tuleb arvesse hollandi (kaljas, loovi-(ma), madrus) või inglise keel (luhva-(ma)), samuti sõnu, mille häälikuline kuju viitab otsesele laenuvõimalusele ladina allikast (ordu, risti-, tiisikus), kuid tõenäoliselt olid ladinakeelsed sõnad kasutusel muukeelses (alamsaksa- või saksakeelses) kontekstis. Üksikute sõnade puhul on (ühe) võimaliku laenuallikana pakutud keeli, millest laenamine on kontaktide tõestamatuse tõttu kaheldav, nt kirik (vanasaksi), poola (keskülemsaksa). Tinglikult võib muudeks laenudeks pidada ka pärisnimest üldnimeks muutunud, algselt heebrea päritolu piiblinimesid, mis on meile laenatud alamsaksa keele kontekstis (aadam, juudas 'äraandja, reetur', koljat). 


\section{Tehistüved}

Tehistüved on kirjakeele rikastamise eesmärgil vabalt loodud uued tüved. Tehistüvesid on EES-is 97. Nende hulka kuuluvad nt aabe, eira-(ma), emba(ma), evi-(ma), hõiva-(ma), hõlva-(ma), kü̈̈l-(ik), laip, laup, liibu-(ma), lünk, lü̈̈me, malbe, meenu-(ma), mõrv, mürsk, neim, nenti-(ma), nõme, nördi-(ma), põrpi-(ma), raal, range, reet-(ma), relv, roim, selmet, selve, sudu, tarni-(ma), tauni-(ma), teim, türp, vandel, veen-(ma).

\section{Kokkuvõte}

Viimase kolmekümne aasta jooksul on teadmised eesti tüvede päritolu kohta täienenud. Täpsustunud on laenukihtide jaotus. Kahe eraldi kihina saab käsitleda vanimaid, indoeuroopa ja indoiraani laene, mis on varem kokku võetud. Samuti saab eraldi kihtidena käsitleda germaani ja skandinaavia laene, mida varem on käsitletud koos germaani laenudena. Eraldi on võimalik välja tuua rootsi laenude vanim kiht, vanarootsi laenud. Slaavi laenukihi asemel on praeguste teadmiste põhjal õigem rääkida vanavene laenukihist.

„Eesti etümoloogiasõnaraamatu” andmetel jagunevad eesti tüved arvuliselt eri kihtidesse järgmiselt.

Uurali tüved

Soome-ugri tüved

Läänemeresoome-permi tüved

Läänemeresoome-volga tüved

läänemeresoome-mari-mordva tüved

läänemeresoome-mari tüved

läänemeresoome-mordva tüved

Läänemeresoome-saami tüved

Läänemeresoome tüved

Lõuna-läänemeresoome tüved

eesti-liivi-vadja tüved

eesti-liivi tüved

eesti-vadja tüved

Eesti ja tundmatu päritoluga tüved

häälikuliselt ajendatud eesti tüved tüvede koondumisel tekkinud tüved tundmatu päritoluga tüved

Indoeuroopa laentüved

Indoiraani ja algiraani laentüved

Balti laentüved

Germaani laentüved

Skandinaavia laentüved
97-149

134-206

$42-85$

$103-158$

$18-28$

$18-29$

67-101

$110-174$

960-1368

90-130

9-11

58-86

23-33

746-816

458-520

36-44

252

16-40

22-39

162-235

193-315

29-62 


$\begin{array}{lc}\text { Vanavene laentüved } & 41-54 \\ \text { Vanarootsi laentüved } & 14-33 \\ \text { Rootsi laentüved } & 61-140 \\ \text { Eestirootsi ja soomerootsi laentüved } & 23-32 \\ \text { Alamsaksa laentüved } & 476-659 \\ \text { Saksa laentüved } & 356-506 \\ \text { Baltisaksa laentüved } & 43-56 \\ \text { Vene laentüved } & 228-274 \\ \text { Läti laentüved } & 31-43 \\ \text { Soome laentüved } & 197-212 \\ \text { Muud laentüved } & 6-18\end{array}$

Tehistüved

Arvudki näitavad etümoloogiaalaste teadmiste arengut. Näiteks on tunduvalt suurem kindlaks tehtud balti laenude hulk, mis 1983. aastal oli 94-156 ehk 1,7-2,82 \% (Rätsep 1983: 545), praegu on aga 162-235 ehk 3,0-4,3\%. ${ }^{3}$ See osutab balti laenude alase uurimistöö tulemuslikkusele. Oluliselt väiksem on kindlate alamsaksa laenude hulk. 1983. aasta andmetel oli neid 771 ehk 13,92 \% (Rätsep 1983: 546), praegu aga ainult 476 ehk 8,8 \%. Põhjuseks on ilmselt asjaolu, et EES-is on nende tüvede puhul rohkem arvesse võetud ka teisi laenuvõimalusi, mistõttu rohkem tüvesid on arvatud kaheldavateks alamsaksa laenudeks. (Mõne rühma suuruse muutuse põhjuseks võivad olla nn etümoloogiavälised asjaolud, nt muutused ÕS-i sõnavalikus või erinevused andmete kogumise metoodikas. Nt soome laenude hulk on kahekordistunud, sest EES-is on arvatud eraldi soome laenudeks ilmselgelt soome keelest laenatud tuletised tüvedest, mis esinevad eesti keeleski, Huno Rätsep on loendanud aga ainult soome keelest laenatud tüvesid.)

Oluliseks etümoloogilise uurimistöö tulemuslikkuse näitajaks võib pidada eesti ja tundmatu päritoluga tüvede hulka. Eelkõige peaks just see ikka veel arvukas tüvede rühm innustama kõiki praegusi ja tulevasi etümolooge tööd jätkama. Avastamisrõõmu peaks pakkuma ka seni ainult läänemeresoome vastetega tüvede uurimine, sest nendegi kaugem päritolu ootab alles selgitamist. Täiendavat uurimist vajavad kõik kaheldava etümoloogiaga sõnad.

Artikkel on valminud osaliselt ETF-i grandi 9367 raames.

\footnotetext{
${ }^{3}$ Käesoleva ja Huno Rätsepa (1983) ülevaate andmed ei ole muidugi päris täpselt võrreldavad. Mõnevõrra erineb lähtematerjal: Huno Rätsepa lähtematerjaliks olid 1976. aasta „Õigekeelsussõnaraamatus” sisalduvad tüved (välja oli jäetud uuem rahvusvaheline sõnavara), EES sisaldab „Eesti õigekeelsussõnaraamatu ÕS 2006” tüvesid (võõrtüved on samuti kõrvale jäetud). Ka tüvede rühmitamises on erinevusi. Üldmulje kahe kokkuvõtte vahelisel ajal toimunud arengust võib siiski saada.
} 


\section{Kirjandus}

A r i s t e, Paul 1937. Mõningaid alamsaksa laensõnu. - Eesti Keel, nr 5, lk 132140.

Ari s t e, Paul 1940. Georg Mülleri saksa laensõnad. - Acta et Commentationes Universitatis Tartuensis B, kd 46, nr 1. Tartu.

B e r e c z ki, Gábor 1988. Geschichte der wolgafinnischen Sprachen. - The Uralic languages. Description, history and foreign influences. Handbuch der Orientalistik. Achte Abteilung. Handbook of Uralic Studies. Kd I. Toim D. Sinor. Leiden-New York-København-Köln: E. J. Brill, lk 314-350.

B lok l a nd, Rogier 2009. The Russian Loanwords in Literary Estonian. (Veröffentlichungen der Societas Uralo-Altaica, kd 78.) Wiesbaden: Harrassowitz Verlag.

EES = Iris Metsmägi, Meeli Sedrik, Sven-Erik Soosaar, Eesti etümoloogiasõnaraamat. Tallinn: Eesti Keele Instituut, Eesti Keele Sihtasutus, 2012.

EKG I = Mati Erelt, Reet Kasik, Helle Metslang, Henno Rajandi, Kristiina Ross, Henn Saari, Kaja Tael, Silvi Vare, Eesti keele grammatika I. Morfoloogia. Sõnamoodustus. Toim M. Erelt, T. Erelt, H. Saari, Ü. Viks. Tallinn: Eesti Teaduste Akadeemia Eesti Keele Instituut, 1995.

$\mathrm{H}$ of s tra, Tette 1985. Ostseefinnisch und Germanisch. Frühe Lehnbeziehungen im nördlichen Ostseeraum im Lichte der Forschung seit 1961. Groningen: Rijksuniversiteit te Groningen.

Karls s o n, Fred 2002. Üldkeeleteadus. Tõlkinud ja kohandanud R. Pajusalu, J. Valge, I. Tragel. Tallinn: Eesti Keele Sihtasutus.

Ki p a r s k y, Valentin 1936. Fremdes im Baltendeutsch. (Mémoires de la Société Néo-philologique de Helsingfors, kd 11.) Helsinki: Société Néo-philologique.

K o i v u l e h t o, Jorma 1999. Varhaiset indoeurooppalaiskontaktit: aika ja paikka lainasanojen valossa. - Pohjan poluilla. Suomalaisten juuret nykytutkimuksen mukaan. Toim P. Fogelberg. (Bidrag till kännedom av Finlands natur och folk, kd 153.) Helsinki: Societas Scientiarum Fennica, lk 207-236.

LÄGLOS I = A. D. Kylstra, Sirkka-Liisa Hahmo, Tette Hofstra, Osmo Nikkilä, Lexikon der älteren germanischen Lehnwörter in den ostseefinnischen Sprachen. Kd I. Amsterdam-Atlanta: GA, 1991.

M u s t, Mari 2000. Vene laensõnad eesti murretes. Tallinn: Eesti Keele Sihtasutus.

M ä g i s t e, Julius 1962. Äldre ryska lånord i estniskan särskilt i det gamla estniska skriftspråket. (Lunds Universitets Årsskrift. N. F. Avd. 1. Kd 55, nr 1.) Lund: CWK Gleerup.

R a a g, Raimo 1988. Nunn, prilla, koka ja teised. Eesti keele rootsi laensõnadest. - Keel ja Kirjandus, nr 11, lk 655-664, nr 12, lk 725-732.

$\mathrm{R}$ äts e p, Huno 1976. Soome laenudest eesti kirjakeeles. - Keel ja Kirjandus, nr 4, lk 210-216.

R ät s e p, Huno 1983. Eesti kirjakeele tüvevara päritolu. - Keel ja Kirjandus, nr 10, lk 539-548.

Ti b e r g, Nils 1962. Estlandssvenska språkdrag. (Estlandssvenskarnas folkliga kultur, nr 6. Acta academiae regiae Gustavi Adolphi, kd 28.) Uppsala-Köpenhamn: A.-B. Lundequistska bokhandeln, Ejnar Munksgaard.

V a b a, Lembit 1997. Uurimusi läti-eesti keelesuhetest. Tallinn-Tampere: Eesti Keele Instituut, Tampereen yliopiston suomen kielen ja yleisen kielitieteen laitos. 
$\mathrm{V}$ a b a, Lembit 2011. Balti laenude uurimine avab meie kauget minevikku. - Keel ja Kirjandus, nr 10, lk 734-763.

ÕS 2006 = Eesti õigekeelsussõnaraamat ÕS 2006. Koost Tiiu Erelt, Tiina Leemets, Sirje Mäearu, Maire Raadik. Toim T. Erelt. Tallinn: Eesti Keele Instituut, Eesti Keele Sihtasutus. http://www.eki.ee/dict/qs2006/.

\section{The origin of the word stems of standard Estonian: a statistical overview}

Keywords: lexicology, etymology, etymological dictionary, Estonian language

The recently published Estonian Etymological Dictionary (EED) summarizes the research done on the origin of the word stems used in standard Estonian. The basis of the EED entry list are the stems found in the Estonian Orthological Dictionary "ÕS 2006", with the exclusion of recent foreign stems. The given statistical overview of the stems of standard Estonian is based on the EED. In the article, a stem is defined in a narrower sense, also considering the language-historical aspect: a stem is a root morpheme carrying a lexical meaning, which does not contain any historical derivational suffixes and cannot be identified phonetically with any other root morpheme with a lexical meaning. The Estonian word stems can be divided into three big groups: native stems, borrowed stems and artficial stems. In the last 30 years (since Rätsep 1983) the classification of borrowed stems has been further specified in that Indo-European and Indo-Iranian stems are regarded as a separate layer, as are Germanic and Scandinavian ones. The number of established Baltic loans has grown essentially. However, the group of Estonian stems of unknown origin, not having any established equivalent, is still quite numerous. The possibly more distant origin of the stems with exclusively Finnic equivalents is also in need of additional research.

Iris Metsmägi (b. 1968), PhD, Institute of the Estonian Language, senior lexicographer,iris.metsmagi@eki.ee

Meeli Sedrik (b. 1968), MA, Institute of the Estonian Language, lexicographer, meelisedrik@hot.ee

Sven-Erik Soosaar (b. 1973), MA, Institute of the Estonian Language, researcher, sven.soosaar@eki.ee 